\title{
Analyzing the impact of Temperature on Proton Exchange Membrane Fuel Cell performance Using Matlab
}

\begin{abstract}
Aftab Ahmed Khuhro ${ }^{1}$,Intizar Ali $^{2}$, Safiullah $^{2}$
Abstract:

The Proton Exchange Membrane Fuel cell (PEMFC) is a device that converts the chemical energy of hydrogen into electrical energy. It receives hydrogen at anode and oxygen at the cathode side, due to chemical reaction at electrodes electronic current, along with that water and heat is also produced. Heat produced causes problem for current produced, cell performance and may lead to a phase change of water produced. Heat produced may also cause melting of the sensitive membrane and increase losses in a fuel cell. Water produced causes flooding at Electrodes and membrane which requires a specific amount of water only. This study used Mat lab to analyze the impact of temperature on different parameters which have a significant effect on heat and mass flow. The results showed that the performance of Proton Exchange Membrane fuel cell reduces with increase in temperature significantly during operation of the cell. The performance of fuel cell can be enhanced if the temperature of the fuel cell is controlled and kept within limits. Proton Exchange Membrane fuel cell is suitable for transport, automobile, and other applications.
\end{abstract}

Keywords: Heat; Mass; Fuel Cell; Transport; Management; Issues; Mass flow; Temperature; Matlab.

\section{Introduction}

In the beginning of this century, the world has realized the shortage of fossil fuels which include mainly coal, gas, and oil. Most of worlds energy demand is dependent on these natural resources. It is predicted that these resources will be very close to depletion in 2060. Nuclear, Solar, Wind and other resources are considered as best option to replace the fossil fuels needed in future. However, still there will be a need for fuel to run high speed and heavy-duty vehicles of future and fuel cells are a suitable option for such a need [1].
William Grove is considered to be first to invent fuel cell in 1839. In 1960 NASA first commercialized the fuel cell by using them in their space missions [2]. After that, this technology was less discussed among researchers due to its shortcomings such as high cost and low efficiency. Nonetheless, improving fuel cell performance by improving its design, material and optimizing performance has found new interest among researchers.

Proton Exchange Membrane Fuel cells are the power source of future. Many researchers are working on this technology to improve its performance and make it compatible with

\footnotetext{
${ }^{1}$ Energy system Engineering, Sukkur IBA University, Sukkur, Pakistan

${ }^{2}$ Department of Mechanical Engineering Technology, The Benazir Bhutto Shaheed University of Technology and Skill Development, Khairpur, Pakistan

Corresponding Email: aftab.mere17@iba-suk.edu.pk 
Aftab Ahmed Khuhro (et al.), Analyzing the impact of Temperature on Proton Exchange Membrane Fuel Cell

other fossil fuel technologies. PEMFCs use pure hydrogen as fuel which can be produced using solar or wind power. Hence this technology becomes clean, sustainable and emission-free technology [1].

PEMFCs consist of a membrane, electrodes, gas diffusion layer, bipolar plates, and current collectors [2]. Hydrogen at anode breaks into proton and electron. The membrane allows proton only to pass through and electrons flow through the external path to do some work. When hydrogen breaks at anode due to catalyst action, it is exothermic reaction hence heat is released [3]. Water is produced at cathode when proton from membrane and oxygen through flow channels combine at cathode [4]. The reaction that occurs on both sides of the membrane is given below.

$$
\begin{aligned}
& \text { Anode } \quad H_{2}(\mathrm{~g}) \rightarrow 2 H^{+}(a q)+2 e^{-} \\
& \text {Cathode } \\
& \begin{array}{l}
\underset{2}{2} \mathrm{O}_{2}(g)+2 H^{+}(a q)+2 e^{-} \\
\rightarrow 2 \mathrm{H}_{2} \mathrm{O}(l)
\end{array} \\
& \mathrm{H}_{2}(g)+\frac{1}{2} \mathrm{O}_{2}(g) \rightarrow \mathrm{H}_{2} \mathrm{O}(\mathrm{l}) \\
& + \text { heat }+ \text { electricity }
\end{aligned}
$$

Heat and water produced are required in specific amount only [5]. If there is excessive heat, it will melt sensitive membrane and affect the efficiency drastically. And if water produced is in the excessive amount, it will cause flooding at electrodes, reducing the active area for reaction and reduce cell performance [6]. Hence this study aims to analyze different fuel cell parameters which can affect heat and mass transfer phenomenon directly or indirectly. The connection of several fuel cell units in series and parallel will add up voltages and current which might be utilized in electric vehicles. This shows the importance of fuel cell electricity generation for the automobile industry.

In order to optimize the performance of fuel cell, optimizing heat and mass problem is necessary. Most of fuel cell performance parameters depend on heat and mass transfer phenomenon [9].

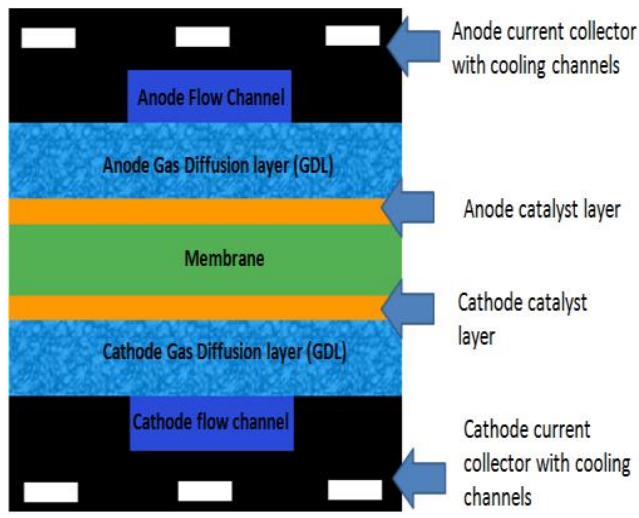

Fig. 1. PEM Fuel Cell diagram [3].

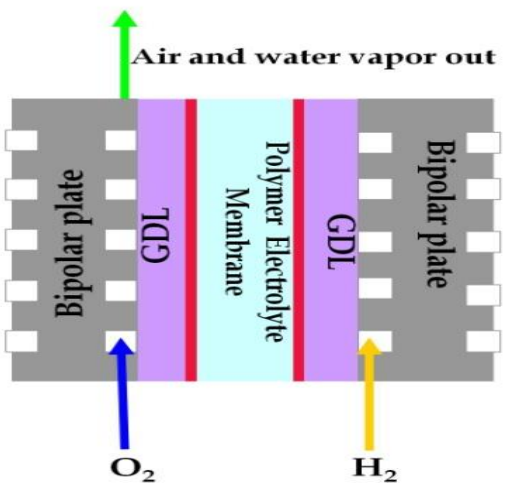

Fig. 2. Flow channels and flow directions [5].

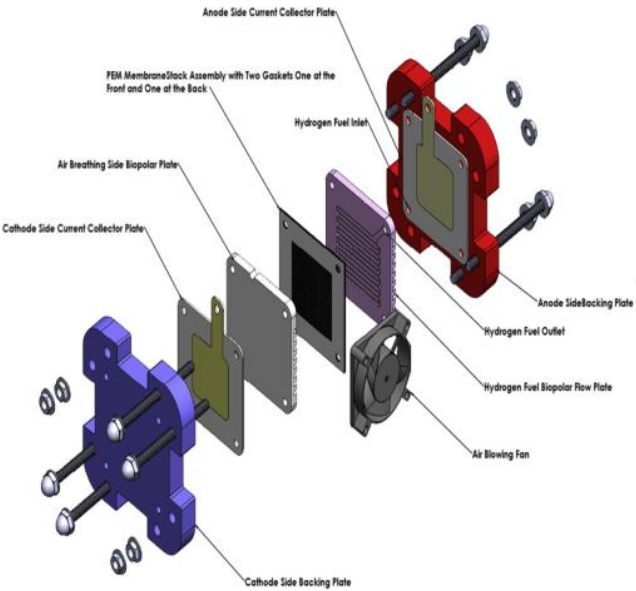

Fig. 3. Exploded view of PEM Fuel cell [16]. 
Aftab Ahmed Khuhro (et al.), Analyzing the impact of Temperature on Proton Exchange Membrane Fuel Cell

\section{Methodology}

This study is based on Numerical analysis of heat and mass transfer issues due to variation of different parameters during operation of the fuel cell. This paper focuses on the impact of temperature variation during cell working and observes the impact on the performance of cell by choosing a different range of operating parameters and analyzed them using the available commercial software. Rather choosing many parameters and observing their effect cell this study is focused on the temperature of the cell which is considered as a most important factor of fuel cell performance. Thus, understanding the fuel cell temperature and its behavior becomes very important.

\subsection{Mass transport and Water Management}

In order to produce the continuous power, we need a continuous supply of fuel at the anode side of the cell. Added with that excessive surplus water produced as the output of reaction should be removed continuously. Voltage and current reduction may be caused due to three kind of losses of fuel cell activation, concentration and ohmic losses [10].

Mass transport is a flow of species within the cell and by optimizing flow and analyzing their effect on cell performance we can predict cell behavior. Water produced may cause the membrane to rupture or occupy active places where reaction needs to take place [11].

$$
\sum\left(m_{i}\right) \text { in }=\sum\left(m_{i}\right) \text { out }
$$

Mass balance of cell system should be mass that goes into system equals that leaves the system.

$$
w_{e l}=n_{\text {cell }} V_{\text {cell }} I
$$

However, cell power can be expressed as given in equation above where n_cell represents the number of cells, V_cell represents cell voltage and I is current of cell.
The higher flow rates cause the better distribution of reactants. If the flow rate is too high that may rupture sensitive membrane. There are basically two types of flow within the cell. One is by convection that occurs in flow channels and the other is diffusive which is due to pores of diffusion layer and electrodes [12].

Hence the study of mass transport and water management become important to properly design fuel cell. Different parameters and constants are used to study the behavior of cell performance when temperature changes with time of operation.

TABLE I. The parameters and constants used in this study to analyze the effect of temperature on fuel cell performance.

\begin{tabular}{|l|l|}
\hline Parameters symbol & Constant value \\
\hline $\begin{array}{l}\text { Thermal on } \\
\text { conductivity (k) }\end{array}$ & $\begin{array}{l}\text { Depends } \\
\text { material }\end{array}$ \\
\hline $\begin{array}{l}\text { Heat transfer rate } \\
(\mathrm{q})\end{array}$ & ------- \\
\hline $\begin{array}{l}\text { Ideal gas constant } \\
(\mathrm{R})\end{array}$ & 8.314 \\
\hline $\begin{array}{l}\text { Faraday's constant } \\
(\mathrm{F})\end{array}$ & 96487 \\
\hline $\begin{array}{l}\text { Transfer coefficient } \\
(\alpha)\end{array}$ & 0.5 \\
\hline Enthalpy & $\begin{array}{l}\text { Depends } \\
\text { temperature }\end{array}$ \\
\hline $\begin{array}{l}\text { Thermal Resistance } \\
(\mathrm{R})\end{array}$ & ------ \\
\hline
\end{tabular}

\subsection{Heat Management}

The temperature in PEMFCs is always unsteady even if flow rate at both electrodes is kept constant. Temperature variations within the cell due to water phase change, heat produced by the chemical reaction, water flooding within the cell and air convection [13]. 
Aftab Ahmed Khuhro (et al.), Analyzing the impact of Temperature on Proton Exchange Membrane Fuel Cell

Determining heat distribution within the cell is key to determine temperature variations and predict them properly. Operating temperature is an important parameter that can affect the efficiency of the cell. Temperature control, distribution and dynamic response are very important to understand for better performance of the cell. It is necessary for proper operation of fuel cell stack that optimum values should be known for parameters such as temperature. Some researcher has shown that temperature has the greatest effect on cell performance [14].

Operation of fuel cell stack is an uncertain process and the temperature is a parameter that has the highest uncertainty during operation. Water transport is directly affected by operating temperature of the cell. It also affects flow species, removal of water, and flooding at electrodes [15].

Heat distribution can be determined using energy balance on the system. The energy balance depends on several factors such as power produced, reactions and heat loss on walls of the cell [16].

The enthalpy of a system that enters the system is equal to the enthalpy of products plus heat generated. The rate of heat transfer with cross-section area $\mathrm{A}$ is given below.

$q_{x}=-k A \frac{d T}{d x}$

Where $\mathrm{k}$ is thermal conductivity and $\frac{d T}{d x}$ is a temperature gradient. $\mathrm{L}$ represents the length and $\mathrm{T}_{1}$ and $\mathrm{T}_{2}$ are initial and final temperatures.

$$
q_{x}=k \frac{T_{1}-T_{2}}{L}
$$

Thermal resistance associated with conduction in the plane wall is given as

$$
R_{\text {cond }}=\frac{T_{1}-T_{2}}{q_{x}}=\frac{1}{k A}
$$

Heat transfer through conduction between two adjacent materials in contact is given as

$$
q=h_{t c} A \Delta T
$$

Where $h_{t c}$ is convective heat transfer coefficient. Thermal resistance associated with heat transfer by convection is given as

$$
R_{\text {conv }}=\frac{T_{1}-T_{2}}{q x}=\frac{1}{h A}
$$

Where $h$ is enthalpy. Since conduction and convection are in series they can be written mathematically as

$$
\begin{gathered}
R_{\text {total }}=\frac{1}{h_{1} A}+\frac{L}{k A}+\frac{1}{h_{2} A} \\
q=U A \Delta T
\end{gathered}
$$

The considering fuel cell walls as composite and in series total heat transfer can be written as equation above where $\mathrm{U}$ is overall heat transfer coefficient.

The fuel cell system runs efficiently when there is precise control of temperature. At higher temperature, the kinetics will be faster and reduce activation losses. But higher temperature may damage the membrane so it is required at an optimum level. Higher temperature will also cause water to vaporize and change its phase from liquid to gas. Small fuel cell stack does not require cooling but larger stack requires cooling for homogenous temperature distribution and control [17].

Heat distribution can be controlled by properly designing flow channels and bipolar plates. Introducing cooling channels with bipolar plates additional heat can be removed.

\section{Results and discussion}

The objective of this study is to analyze and observe the impact of temperature on fuel cell Losses, Performance, Entropy, Current produced, Consumption of fuel and Reversible cell potential.

Temperature is an important parameter that has an effect on heat and mass parameters. Temperature has a low impact on the entropy of mass species during operation of the cell. 
Aftab Ahmed Khuhro (et al.), Analyzing the impact of Temperature on Proton Exchange Membrane Fuel Cell

The entropy of $\mathrm{H}_{2}, \mathrm{O}_{2}$, and water does not show significant change while temperature increases during operation.

Water management at Membrane in cell stack is very important because Ionic current flows through the hydrated membrane. Heat is generated at anode which causes dehydration of membrane. On the other hand, water generated at cathode may cause flooding if generation rate is higher than transport rate. Both the hydration and flooding at cathode depends on heat generated by fuel cell reaction and both dehydration of electrolytic membrane and flooding of cathode must be avoided to get optimum performance of cell stack.

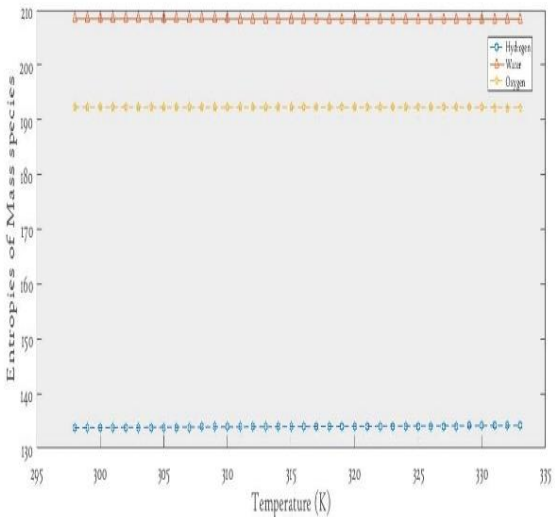

Fig. 4. The impact of temperature on the entropy of mass species.

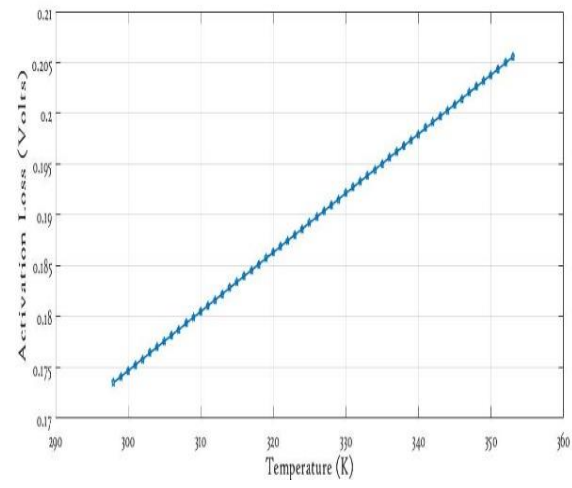

Fig. 5. The impact of temperature on activation losses.
However, the temperature has a significant impact on activation losses of the cell. If temperature increases the activation losses increases with that exponentially. Hence temperature control during operation of the cell becomes very important to limit activation losses. Heat and mass species play an important role in cell performance and are related to temperature directly or indirectly.

Temperature also plays an important role in current produced by the cell, hydrogen consumed at the anode and total electricity produced by the cell. This study shows that if temperature increases with that current produced by cell decrease significantly. The significant loss in total electricity produced is also observed. Due to increase in temperature number of moles consumed at the anode side of PEMFCs also reduces. The less current produced and moles at anode show that performance of cell reduces with increase in temperature. The results show that reversible cell potential also reduces with increase in temperature. Hence temperature has a negative impact on reversible potential which will add further loss in fuel cell performance and efficiency to operate at high temperature.

Temperature has a positive impact on cell current density.

If temperature increases cell electrode kinetics increases along with electrode kinetics limiting current density increases.

The key findings of this study would be following.

1. Temperature has less impact on Entropy but it accelerates the kinetic reaction at first along with an increase in activation losses.

2. Reversible cell potential values reduced with increasing temperature. 
Aftab Ahmed Khuhro (et al.), Analyzing the impact of Temperature on Proton Exchange Membrane Fuel Cell

TABLE II. Effect of temperature on cell current, electricity produced and $\mathrm{H}_{2}$ consumed at the anode.

\begin{tabular}{|c|c|c|c|}
\hline $\begin{array}{c}\text { Temperat } \\
\text { ure (K) }\end{array}$ & $\begin{array}{c}\text { Current } \\
\text { produc } \\
\text { ed (A) }\end{array}$ & $\begin{array}{c}\text { Electrici } \\
\text { ty } \\
\text { produce } \\
\text { d }\end{array}$ & $\begin{array}{c}\text { No of } \\
\text { moles } \\
\text { consum } \\
\text { ed }\left(\mathrm{H}_{2}\right)\end{array}$ \\
\hline 298.15 & 1.9733 & $\begin{array}{c}1.70 \times 10 \\
5\end{array}$ & 0.8835 \\
\hline 303.15 & 1.9467 & $\begin{array}{c}1.67 \times 10 \\
5\end{array}$ & 0.8689 \\
\hline 308.15 & 1.9092 & $\begin{array}{c}1.64 \\
\times 10^{5}\end{array}$ & 0.8548 \\
\hline 313.15 & 1.8788 & $\begin{array}{c}1.62 \times 10 \\
5\end{array}$ & 0.8412 \\
\hline 318.15 & 1.8492 & $\begin{array}{c}1.59 \times 10 \\
5\end{array}$ & 0.8280 \\
\hline 323.15 & 1.8206 & $\begin{array}{c}1.57 \times 10 \\
5\end{array}$ & 0.8151 \\
\hline 328.15 & 1.7929 & $\begin{array}{c}1.54 \times 10 \\
5\end{array}$ & 0.8027 \\
\hline 333.15 & 1.7660 & $\begin{array}{c}1.52 \times 10 \\
5\end{array}$ & 0.7907 \\
\hline 338.15 & 1.7399 & $\begin{array}{c}1.50 \times 10 \\
5\end{array}$ & 0.7790 \\
\hline 343.15 & 1.7145 & $\begin{array}{c}1.48 \times 10 \\
5\end{array}$ & 0.7676 \\
\hline 348.15 & 1.6899 & $\begin{array}{c}1.46 \times 10 \\
5\end{array}$ & 0.7566 \\
\hline 353.15 & 1.6660 & $\begin{array}{c}1.43 \times 10 \\
5\end{array}$ & 0.7459 \\
\hline
\end{tabular}

3. The less fuel was consumed due to increase in temperature which is not good for the overall performance of the cell.
TABLE III. Effect of temperature on reversible cell potential.

\begin{tabular}{|l|l|}
\hline Temperature $(\mathrm{K})$ & $\begin{array}{l}\text { Reversible cell } \\
\text { potential }\end{array}$ \\
\hline 298 & 1.2289 \\
\hline 303 & 1.2247 \\
\hline 308 & 1.2205 \\
\hline 313 & 1.2163 \\
\hline 318 & 1.2120 \\
\hline 323 & 1.2036 \\
\hline 328 & 1.1993 \\
\hline 333 & 1.1909 \\
\hline 343 & 1.1902 \\
\hline 353 & 1.1824 \\
\hline 363 & 1.1740 \\
\hline 373 & 1.1655 \\
\hline
\end{tabular}

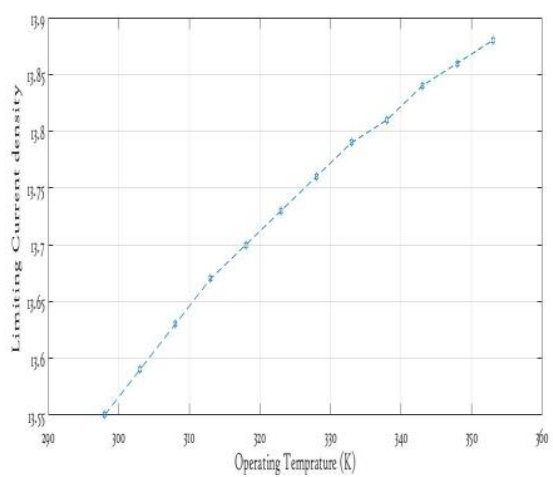

Fig. 6. The impact of Temperature on limiting current density.

\section{Conclusion}

This paper shows that temperature has a significant impact on current produced within fuel cell stack compared to Entropy of mass species. As the temperature rises due to heat released during reaction taking place at Electrodes, current and electricity produced 
Aftab Ahmed Khuhro (et al.), Analyzing the impact of Temperature on Proton Exchange Membrane Fuel Cell

are reduced. There was a continuous drop in hydrogen consumption at Electrodes due to rise in temperature. The lesser consumption of hydrogen fuel at anode leads to the minimum amount of current and electricity production.

Temperature also affects the activation losses of the cell, the increase in temperature active places at anode and cathode of cell show more resistance for reaction. The operation time to calculate cell current and other parameters was chosen 24 hours. During this period number of moles calculated and converted in liters at $25 \mathrm{oC}$ are 19.79 liters.

The number of liters consumed at $80 \mathrm{oC}$ ware 16.70. It can be concluded that with higher temperature cell tends to consume less fuel as compared to low temperature, which will eventually result in low performance and reliability of PEMFCs.

\section{ACKNOWLEDGMENT}

Authors would like to thank Dr. Fareed Hussain Mangi and Dr. Saeed Ahmed Khan Abro for their valuable suggestions. Authors also thank Reviewers for their valuable comments and suggestions.

\section{REFERENCES}

[1] S. Shafiee, \& E. Topal, "When will fossil fuel reserves be diminished?," Energy policy, vol. 37, no. 1, pp. 181-189, 2009.

[2] A. Arvay, A. Ahmed, X.-H. Peng, and A. Kannan, "Convergence criteria establishment for 3D simulation of proton exchange membrane fuel cell," International journal of hydrogen energy, vol. 37, pp. 2482-2489, 2012.

[3] C. Siegel, "Review of computational heat and mass transfer modeling in polymerelectrolyte-membrane (PEM) fuel cells," Energy, vol. 33, pp. 1331-1352, 2008.

[4] A. Arvay, Proton exchange membrane fuel cell modeling and simulation using Ansys Fluent. Arizona State University, 2011.
[5] J. Carton and A. Olabi, "Threedimensional proton exchange membrane fuel cell model: comparison of double channel and open pore cellular foam flow plates," Energy, vol. 136, pp. 185-195, 2017.

[6] R. B. Ferreira, D. Falcão, V. Oliveira, and A. Pinto, "Numerical simulations of twophase flow in proton exchange membrane fuel cells using the volume of fluid method-A review," Journal of Power Sources, vol. 277, pp. 329-342, 2015.

[7] S. Cano-Andrade, A. HernandezGuerrero, M. Von Spakovsky, C. Damian-Ascencio, and J. Rubio-Arana, "Current density and polarization curves for radial flow field patterns applied to PEMFCs (Proton Exchange Membrane Fuel Cells)," Energy, vol. 35, pp. 920927, 2010.

[8] X.-D. Wang, Y.-X. Huang, C.-H. Cheng, J.-Y. Jang, D.-J. Lee, W.-M. Yan, et al., "Flow field optimization for proton exchange membrane fuel cells with varying channel heights and widths," Electrochimica Acta, vol. 54, pp. 55225530, 2009.

[9] D. Spernjak, A. K. Prasad, and S. G. Advani, "In situ comparison of water content and dynamics in parallel, singleserpentine, and interdigitated flow fields of polymer electrolyte membrane fuel cells," Journal of Power Sources, vol. 195, pp. 3553-3568, 2010.

[10]M. Zhukovsky, L. Fomina, and S. Beznosyuk, "Computer modeling of hydrogen fuel cell subsystems: Carbon nanogel electrodes and fractal nanoparticle catalysts," International Journal of Hydrogen Energy, vol. 36, pp. 1212-1216, 2011.

[11]L. Karpenko-Jereb, P. Innerwinkler, A.M. Kelterer, C. Sternig, C. Fink, P. Prenninger, et al., "A novel membrane transport model for polymer electrolyte fuel cell simulations," International 
journal of hydrogen energy, vol. 39, pp. 7077-7088, 2014.

[12] A. Manso, F. Marzo, J. Barranco, X. Garikano, and M. G. Mujika, "Influence of geometric parameters of the flow fields on the performance of a PEM fuel cell. A review," International journal of hydrogen energy, vol. 37, pp. 1525615287, 2012.

[13]P. K. Sinha, C.-Y. Wang, and U. Beuscher, "Transport phenomena in elevated temperature PEM fuel cells," Journal of The Electrochemical Society, vol. 154, pp. B106-B116, 2007.

[14]A. Bryıkoğlu, "Review of proton exchange membrane fuel cell models," International Journal of Hydrogen Energy, vol. 30, pp. 1181-1212, 2005.

[15] J.-H. Jang, W.-M. Yan, and C.-C. Shih, "Effects of the gas diffusion-layer parameters on cell performance of PEM fuel cells," Journal of power sources, vol. 161, pp. 323-332, 2006.

[16] T. Wilberforce, Z. El-Hassan, F. Khatib, A. Al Makky, J. Mooney, A. Barouaji, et al., "Development of Bi-polar plate design of PEM fuel cell using CFD techniques," International journal of hydrogen energy, vol. 42, pp. 2566325685, 2017.

[17] A. A. Khuhro, Y. Ali, M. Najam-Uddin, and S. Khan, "A Technological, Economical and Efficiency Review of Direct Methanol Fuel Cell,". 